\title{
Pelatihan Memanfaatkan Limbah Rumah Tangga Menjadi Barang yang Bernilai Ekonomis pada Kelompok Karang Taruna di Balekambang, Jakarta Timur
}

\author{
Rudeva Juniawaty, Siti Juriah, Kanaria Herwati \\ Universitas Indraprasta PGRI \\ rudeva.j@gmail.com, sitijuriah336@gmail.com, kanariaherwati@gmail.com
}

\begin{abstract}
Abstrak
Tujuan dari kegiatan pengabdian kepada masyarakat ini untuk memberikan pelatihan keterampilan dalam memanfaatkan limbah rumah tangga menjadi barang yang bernilai ekonomis dan layak untuk dipasarkan. Pelatihan dilakukan pada Kelompok Karang Taruna RT 003 RW 05 Kelurahan Balekambang, Condet, Jakarta Timur. Adapun target rencana kegiatan ini adalah salah satu dari tridarma perguruan tinggi yaitu pengabdian kepada masyarakat. Metode yang digunakan oleh Tim Dosen Universitas Indraprasta dalam kegiatan ini adalah dengan memberikan pelatihan keterampilan dengan cara mempresentasikan dan kegiatan praktik langsung dengan mengajarkan beberapa keterampilan membuat aneka hiasan dan barang-barang yang diaplikasikan dengan kain flanel sehingga dapat memiliki nilai ekonomis kepada 10 (sepuluh) remaja Karang Taruna RT 003/05 Kel. Balekambang Kec. Kramat Jati, Jakarta Timur sebagai bekal untuk berwirausaha kelak.
\end{abstract}

Kata Kunci: pelatihan keterampilan, limbah industri, ekonomis

\section{Training on Utilizing Household Waste into Economic Value Items for Youth Organizations in Balekambang, East Jakarta}

\begin{abstract}
The purpose of this community service activity to provide skills training in utilizing household waste into goods of economic value and worth marketable. The training was conducted at Karang Taruna RT 003 RW 05 Balekambang Village, Condet, East Jakarta. The target of this activity plan is one of tridarma universities, namely community service. The method used by Indraprasta University lecturer team in this activity is to provide skills training by presenting and direct practice activities by teaching some skills to make various decorations and items applied with fanel cloth so that it can have economic value to 10 (ten) teenagers Karang Taruna RT 003/05 Kel. Balekambang Kec. Kramat Jati, East Jakarta as a provision for entrepreneurship later.
\end{abstract}

Keywords: skills training, industrial waste, economics

\section{PENDAHULUAN}

Perekonomian Indonesia yang semakin melambat berdampak pada sektor ketenagakerjaan. Berdasarkan data Badan Pusat Statistik (BPS) jumlah pengangguran di Indonesia pada Agustus 2015 sebanyak 7,56 juta orang, bertambah 320 ribu orang dibandingkan dengan periode yang sama tahun 2014 yaitu 7,24 juta jiwa. Sementara jumlah angkatan kerja bertambah 510 ribu orang menjadi 122,38 juta. Secara persentase, Tingkat Pengangguran Terbuka (TPT) pada Agustus 2015 sebesar 6,18\% naik dari 5,94\% pada Agustus 2014. Penduduk bekerja pada Agustus 2015 sebanyak 114,8 juta jiwa berkurang 6 juta jiwa dibandingkan dengan keadaan Februari 2015 dan bertambah 190 ribu orang dibandingkan keadaan Agustus 2014.

Statistik menunjukkan, dari total 114 angkatan yang bekerja hingga Agustus 2015, sebanyak 34,31 juta orang masuk kategori pekerja tidak penuh. Apabila dirinci, pekerja tidak penuh tersebut terbagi lagi menjadi pekerja dengan status setengah pengangguran sebanyak 9,74 juta jiwa dan pekerja paruh waktu 24,57 juta jiwa. Pertambahan 
pengangguran tersebut akibat meningkatnya jumlah angkatan kerja seiring dengan melemahnya daya serap tenaga kerja dari beberapa industri.

Lapangan kerja yang tercipta pun dinilai tak mampu lagi mengimbangi pertumbuhan angkatan kerja baru sehingga menyebabkan angka pengangguran semakin meningkat dari tahun ke tahun. Sementara setiap perusahaan menuntut kualitas sumber daya manusia yang semakin tinggi dan menuntut kekhususan skill yang lebih sulit lagi untuk dipenuhi.

Banyaknya orang kehilangan pekerjaan dan susahnya mencari pekerjaan di tengah krisis ekonomi mendorong orang mencari alternatif untuk berwirausaha sendiri (Laksono,2002).

Salah satu cara untuk mengurangi tingkat pengangguran adalah menjadi wirausahawan (entrepreneur) dengan membuka lapangan pekerjaan sendiri dan orang lain. Untuk menjadi seorang wirausahawan (entrepreneur) tidak harus memerlukan modal yang besar atau pendidikan yang tinggi. Dengan bermodalkan kreativitas, mampu membaca peluang pasar dan mengamati lingkungan sekitar, dapat menjadi modal dasar bagi seseorang untuk memulai suatu usaha. Walaupun untuk memulai suatu usaha bukanlah suatu hal yang mudah, namun jika gigih, ulet dan terus aktif, usaha tersebut dapat berjalan dengan baik. Salah satu usaha yang dapat dimulai dari rumah dan bermodal kecil adalah kerajinan tangan dengan bahan baku stoples plastik, kaleng susu bekas kotak tisu, gulungan bekas tisu maupun gulungan bekas lakban yang dihias dengan aplikasi kain flanel. Pemanfaatan limbah rumah tangga ini juga sekaligus ikut mencanangkan gerakan 3R (reduce, reuse, recycle).

Melihat keaktifan dan potensi dari kelompok remaja di lingkungan Karang Taruna RT 003/05 Kel. Balekambang Condet, sangat disayangkan apabila mereka yang. aktif dan memiliki keinginan untuk terus belajar tidak diberdayakan. Melalui pemberdayaan kelompok remaja karang taruna dengan mengikuti pelatihan keterampilan membuat kerajinan dari barang bekas limbah rumah tangga diharapkan dapat menggali potensi dan kreativitas yang ada pada mereka sehingga dapat menjadi modal jika mereka ingin berwirausaha.

Dilihat dari keadaan yang ada seperti yang kami paparkan di atas, diperlukan kegiatan pelatihan termasuk motivasi pada kelompok remaja karang taruna mengenai pengetahuan tentang pemanfaatan limbah rumah tangga menjadi barang yang bernilai ekonomis dengan mengolahnya menjadi barang yang memiliki nilai jual ekonomis. Mereka akan diberdayakan oleh tim abdimas Universitas Indraprasta PGRI yang terdiri dari 3 (tiga) orang dosen. Selain itu juga dalam kesempatan ini, tim abdimas juga akan berusaha untuk memperkenalkan seperti apa peluang usaha yang bisa dimanfaatkan melalui pengolahan limbah yang menjadi kerajinan tangan ini sehingga kelompok remaja mendapat pemahaman bagaimana memanfaatkan limbah rumah tangga menjadi barang yang memiliki nilai untuk menghasilkan uang.

Kegiatan pengabdian kepada masyarakat ini bertujuan antara lain:

1. Memberikan pengetahuan akan manfaat limbah rumah tangga sehingga pola pikirnya berubah bahwa limbah rumah tangga jika dikelola dan dikreasikan dengan baik bukan lagi menjadi sampah yang hanya mengotori lingkungan.

2. Membantu mengurangi sampah rumah tangga, mengingat lingkungan di Jl. Kayumanis Gg. AMD 28 adalah wilayah yang selalu terkena banjir karena berada pada bantaran Kali Ciliwung. 
Vol. 2, No. 2, July, 2021, pp. $142-146$

e-ISSN: 2722-2004

\section{Training on}

Utilizing

Household

Waste into

Economic

Value Items

\section{for Youth}

Organizations in

Balekambang,

East Jakarta

R. Juniawaty, Siti Juriah, K. Herwati

3. Memberikan pelatihan keterampilan kerajinan tangan dengan memanfaatkan limbah rumah tangga dipadukan dengan aplikasi kain flanel

4. Memberikan motivasi kepada para remaja karang taruna peserta pelatihan untuk berwirausaha di bidang industri kreatif berbasis lingkungan dimulai dari usia muda sehingga tidak lagi mengandalkan industri besar sebagai lapangan pekerjaan mereka

\section{METODE PELAKSANAAN}

Kegiatan pengabdian masyarakat ini bertema Pelatihan Keterampilan Pemanfaatan Limbah Rumah Tangga Menjadi Barang yang Bernilai Ekonomis pada Kelompok Karang Taruna. Kegiatan dilaksanakan pada November 2016 di Jl. Kayumanis Gg. AMD 28 No. 10 Rt. 003/ 05 Kel. Balekambang Kec. Kramat Jati - Condet Jakarta Timur. Peserta dalam kegiatan ini ialah Kelompok Karang Taruna RT 003/05 Kel. Balekambang Kec. Kramat Jati - Condet Jakarta Timur yang juga menjadi mitra dalam pelaksanaan kegiatan ini.

\section{HASIL DAN PEMBAHASAN}

Hasil evaluasi setelah mengadakan kegiatan pelatihan keterampilan pemanfaatan limbah rumah tangga pada kelompok karang taruna, tim melihat bahwa animo para remaja karang taruna sangatlah antusias. Hal ini dibuktikan dengan pertanyaan-pertanyaan yang diajukan kepada tutor sangatlah beragam dan sangat berkaitan erat dengan semangat berbisnis dan berinvestasi. Selain itu dengan diberikannya contoh penerapan yang dimulai dengan menuangkan ide kreatif dari masing-masing individu juga memudahkan masing-masing individu untuk berkreasi dan menciptakan hasil yang memuaskan.

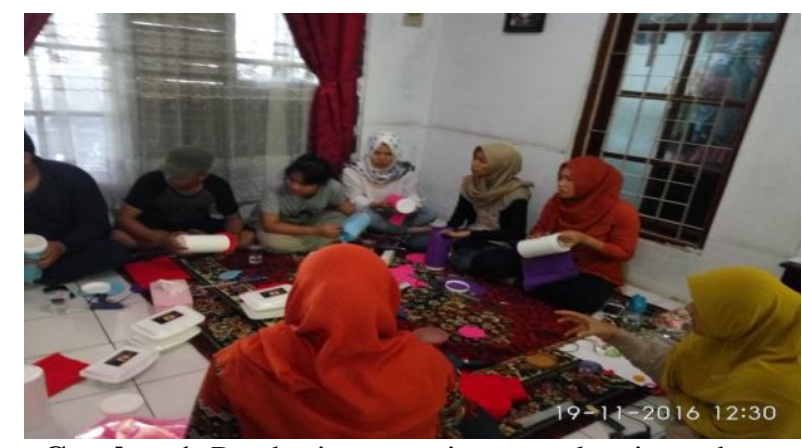

Gambar 1. Pemberian materi tentang kewirausahaan

Teori-teori dan praktik yang telah diberikan oleh tutor, diharapkan dapat memberi motivasi bagi para remaja karang taruna untuk ke depannya mengubah pola pikir mereka bahwa untuk memiliki usaha tidak harus memiliki modal yang cukup. Selain itu untuk membuat suatu produk tidak harus menunggu ide yang cemerlang, akan tetapi ide tersebut bisa muncul dari hal kecil di sekitar seperti dari hobi yang dimiliki. Adapun salah satu hasil luaran dari penyuluhan dan pelatihan ini adalah mereka mulai sadar akan pentingnya berbisnis dan berinvestasi sedini mungkin, dan juga bisa membuat mereka lebih mandiri lagi. Para remaja juga meminta kepada tim untuk diadakan kembali acara serupa di lingkungan sekitar mereka. 
Pada gambar 2 berikut merupakan hasil karya dari salah satu peserta dalam membuat produk yang memiliki daya jual sebagai bentuk aplikasi awal dalam berbisnis dan berinvestasi.

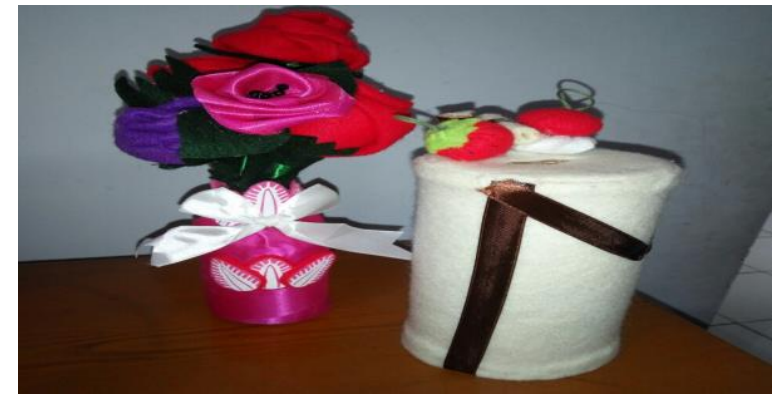

Gambar 2. Gambar hasil karya salah satu remaja Karang Taruna

\section{SIMPULAN}

Simpulan dari semua kegiatan penyuluhan dan pelatihan yang telah dilaksanakan yaitu peserta memiliki kesadaran akan pentingnya berwirausaha dan berbisnis. Peserta juga memiliki kesadaran akan pentingnya menginvestasikan keuntungan atau pendapatan yang dimiliki yaitu hasil dari berwirausaha dan berbisnis. Selain itu, kegiatan ini juga mampu menciptakan semangat kepada para remaja karang taruna untuk bisa memanfaatkan limbah rumah tangga yang berada di sekelilingnya untuk diolah menjadi produk yang layak jual. Kegiatan ini juga memberikan kesadaran kepada para remaja Karang Taruna untuk mencintai lingkungan dengan pemanfaatan limbah atau barang bekas.

Berdasarkan kegiatan ini, tim menyadari bahwa melaksanakan pengabdian kepada masyarakat merupakan kewajiban bagi para dosen. Ke depannya, diharapkan para dosen bisa melakukan pengabdian kepada masyarakat lebih baik lagi dengan pemberian materi yang lebih beragam dan dapat bermanfaat bagi masyarakat pada umumnya.

\section{DAFTAR PUSTAKA}

Astamoen, M. (2008). Entrepreneurship Dalam Perspektif Kondisi Bangsa Indonesia. Bandung: Penerbit ALFABETA

Hynes, W. (2005). Memulai dan Menjalankan Bisnis Kerajinan Tangan. Alih bahasa: Dian Yulinati. Jakarta: Abdi Tandur.

Info KLH. (2009). Ayo Kelola Sendiri Sampah Rumah Kita ...... !!!. Deputi

Komunikasi Lingkungan dan Pembedayaan Masyarakat Kementrian Lingkungan Hidup. (Diakses tanggal 5 Oktober 2013)

Lengkana, L. (2009). Kreasi Unik dari Plastik. Jakarta: PT Gramedia Pustaka Utama.

Marzuki, S. (2010). Pendidikan Nonformal. Dimensi dalam Keaksaraan Fungsional, Pelatihan, dan Andragogi. Bandung: PT Remaja Rosdakarya.

Peluang Usaha. Edisi 03 - Th IX. 22 November-5 Desember 2013

Pratama, A. N. (2009). Dari Sampah Jadi Duit. Yogyakarta: Makna Pustaka

Purbasari, R. N. Wijayanti, R. (2012). Aplikasi Yo-Yo Untuk Pemula. Jakarta: Kriya Pustaka.

Tabloit Peluang Usaha. Edisi 08. Th IX. 31 Januari-13 Februari 2014. 
KANGMAS: Karya Ilmiah Pengabdian Masyarakat, Vol. 2 No. 2, July 2021 - 146

http://journal.neolectura.com/index.php/kangmas

Vol. 2, No. 2, July, 2021, pp. $142-146$

e-ISSN:

2722-2004

Valenta Sari, E. (5 November 2015). BPS : Jumlah Pengangguran Bertambah 320 Ribu Orang Akibat PHK, CNN Indonesia, diakses pada 22 Agustus 2016, http://www.cnnindonesia.com/ekonomi/20151105130747-92-89668/bpsjumlah-pengangguran-bertambah-320-ribu-orang-akibat-phk/

\section{Training on}

\section{Utilizing}

Household

Waste into

Economic

Value Items

\section{for Youth}

Organizations in

Balekambang,

East Jakarta

R. Juniawaty, Siti Juriah,

K. Herwati 